\title{
Survey of indoor air pollution and health symptoms at residential buildings
}

\author{
Sreemoyee Sarkar, Abantika Nandy, Soumendra Nath Talapatra*, \\ Rajlaxmi Basu, Aniruddha Mukhopadhyay \\ Department of Environmental Science, University of Calcutta \\ 51/1 \& 2 Hazra Road, Kolkata 700019, India \\ *Phone: 91-33-2461-5445 \\ *E-mail address: ecologylive@yahoo.co.in
}

\begin{abstract}
This survey work summarizes the generation of indoor air pollutants (IAPs) through household products and activities and also the probable health symptoms of IAPs were discussed through questionnaire in the residential buildings of urban and semi urban area when compared to rural (control) area by door to door survey. The IAPs are categorized as physical, chemical and biological and surveyed as per the product(s) usage in the closed room of buildings. The survey results of IAPs generated from household products and activities, these are asbestos, fine particulate matters and ash as physical pollutants. The chemical pollutants are carbon mono and di oxide gases, phthalates; DDT, chlordane, heptachlor, o-phenylphenol; PBDEs, Formaldehyde, Other Aldehydes, lead, benzene, chloroform, para-dichlorobenzene, methylene chloride, perchloroethylene, styrene, benzene, formaldehyde, terpenes, styrene, phthalate esters, toluene, Propellant, pesticides, PAH, NOx, acrylamide, VOCs, acetone, $\mathrm{HCl}$ gas and biological pollutants are bacteria, fungi, viruses, house dust mites, animal dander; cockroaches, microbial spore. In respect to established health impact data, the health symptoms were recorded after survey in two areas viz. urban and semi urban area. The health symptoms were recorded as eye, nose, and throat irritation; allergic reactions, respiratory irritation, aggravated asthma, influenza and other infectious diseases may be the generation of IAPs. The urban and semi urban area are compared with rural (control) area in which no symptoms were found as per discussion. In the present survey it was concluded that the generation of IAPs may from household products and activities in the urban and semi urban area due to less ventilation facilities when compared to rural (control) area. This is a preliminary observation, further researches are needed in relation to measurement of physical, chemical and biological indoor pollutants in closed room of residential buildings and also health hazards study of residents by haematological, biochemical, enzymological and genotoxicological parameters.
\end{abstract}

Keywords: Indoor Air pollution; Indoor Air Quality; Indoor Air Pollutants; Household products; Health hazards symptoms; Ventilation

\section{INTRODUCTION}

The physical, chemical and biological pollutants found in indoor air often several times higher than outdoors. In closed chamber, these cause effects ranging from odour, annoyance 
and irritation to illness, cancer and even death (Health Canada, 1995). Over the past twenty years indoor air quality as develop of indoor air pollution has received much attention. Many complaints of health impacts in relation to indoor air pollution arise and the causes of these complaints are often not identified, despite thorough measurements of indoor air in modernized as well as urbanized residential buildings. To some extent, these complaints have been blamed on energy-efficiency measures.

In a workshop on Indoor Air Quality Management organized by the European Commission, it was identified that the attainment of health and comfort in the indoor environment, combined with energy efficiency, requires both minimization of human exposure to indoor air pollution, i.e. source control, and a well functioning and energyefficient heating, ventilating or air-conditioning system (Bluyssen, 1991). As a result of this workshop, the "European Audit Project to Optimize Indoor Air Quality and Energy Consumption in Office Buildings" was started. Fifty-six office buildings in nine European countries were audited during the heating season of 1993-1994 (Bluyssen, et al., 1995a). The audits were performed according to a standard procedure, within the framework of the "European Audit Project to Optimize Indoor Air Quality and Energy Consumption in Office Buildings", sponsored by the European Community through the Joule I1 programme. The main aim of this EC-Audit was to develop assessment procedures and guidance on ventilation and source control, to help assure good indoor air quality and optimize energy use in office buildings. Fifteen institutes from 11 countries (the Netherlands, Denmark, France, Belgium, United Kingdom, Greece, Switzerland, Finland, Norway, Germany and Portugal) participated. Europe-wide agreement was reached on a common method that was developed to investigate mainly indoor air quality in office buildings, including a questionnaire and walk-through survey checklist (Clausen, et al., 1993).

It refers to the physical, chemical, and biological characteristics of air in the indoor environment within a home, building, or an institution or commercial facility. Indoor air pollution is a concern in the developed countries, where energy efficiency improvements sometimes make houses relatively airtight, reducing ventilation and raising pollutant levels. Indoor air problems can be subtle and do not always produce easily recognized impacts on health. Different conditions are responsible for indoor air pollution in the rural areas and the urban areas. The concentration of volatile organic compounds (VOCs) measured in indoor air are often significantly higher than outdoors. There are various potential origins such as human activities, infiltration from outdoor air, heating ventilation and air conditioning (HVAC) systems (Wolkoff, 1995; Fanger, Lauridsen, Bluyssen, et al. 1988), bacterial and fungal activities (Rivers, Pleil and Wiener, 1992; Batterman, Bartoletta and Burge, 1991) and product emissions (Wallace, Pellizzari, Leaderer, et al. 1987; Wolkoff 1995; Wolkoff, Jensen, Kjaer, et al. 1996; Hodgson, Rudd, Beal, et al. 2000). The concentrations are usually orders of magnitude below the occupational threshold limit values (TLVs). However, some VOCs may be present above their human odour thresholds (OTs). Beside odor annoyance, VOCs at sub-TLV level may cause non-specific health effects such as eye and upper respiratory airway irritation, headache and increased weariness (Molhave, 1986; Molhave, 1991; Seifert, 1999 and Pitten, Bremer and Kramer, 2000; Chan, 2003).

Health effects due to indoor air pollutants may be short-term as well as long-term. Short-term problems include a stuffy, odorous environment and symptoms such as burning eyes, skin irritation, and headaches. Long-term health problems have a longer latency period or are chronic in nature. The magnitude and duration of detrimental health effects are influenced by the time of exposure, concentration, presence of a preexisting unhealthy condition and age. Health conditions involving some allergic reactions, including 
hypersensitivity pneumonitis, allergic rhinitis, and some types of asthma, are triggered by bioaerosols. Symptoms related to bioaerosols include sneezing, coughing, shortness of breath, fever, and dizziness. Infections such as influenza, measles, and chicken pox are also transmitted through the air. Overall, poor air quality may be responsible for a decrease in work performance, general feeling of poor health, reduced ability to concentrate, or illness (WHO, 2002).

The present study aims to know indoor air pollution may generates by using household products and activities at residential buildings and health symptoms by door to door questionnaire survey.

\section{MATERIALS AND METHODS}

\section{1. Study Area}

The study areas were selected as per use of household products and activities in modernized house. The survey was carried out at 3 areas as per lifestyle as well as urban, semi urban and rural area viz (i) Semi Modern lifestyle and Urban area, Bhowanipur (latitude $=22^{\circ} 31^{\prime} \mathrm{N}$ and longitude $=88^{\circ} 21^{\prime} \mathrm{E}$ ), (ii) Semi Modern lifestyle and Semi Urban area, Sonarpur (latitude $=22^{\circ} 26^{\prime} \mathrm{N}$ and longitude $=88^{\circ} 25^{\prime} \mathrm{E}$ ), (iii) Normal lifestyle and Rural area, Jhargram as control area (latitude $=22^{\circ} 27^{\prime} \mathrm{N}$ and longitude $=87^{\circ} 05^{\prime} \mathrm{E}$ ). Total 10 houses were surveyed in each area.

\section{2. Questionnaire}

On the basis of following questionnaire the survey was done:

1. Name of the Person:

2. Age:

3. Sex:

4. Health Hazards Symptoms:

$\square$ No symptoms $\quad \square$ Dizziness $\quad \square$ Eye irritation $\quad \square$ Respiratory problems

Nasal congestion $\quad \square$ Running nose $\quad \square$ Headache

Others with description

5. Symptoms usually occurs in which room?...

6. These symptoms occur at what time? Day or Night

7. Mention the season when do symptoms occur?

Summer. Monsoon. or Winter.

8. After leaving the room do symptoms persist?

Yes. or No

9. When were symptoms first noticed? (Month and Year)

10. Check any new events, changes or hobbies in your home environment that began within a month of the date given in question number 9 . If you identify changes in the indoor environment, put the mark $(\checkmark)$ in the appropriate place of the following sections - 
- New home $\square$ yes $\square$ No

- New construction $\square$ yes $\square$ No

- New smoker $\square$ yes $\square$ No

- New weatherization $\square$ yes $\square$ No

- New carpeting $\square$ yes $\quad \square$ No

- Old carpeting $\square$ yes $\quad \square$ No

- Addition of gas heating, cooking / cloths drier $\square$ yes $\quad \square$ No

- New hobby using varnishes, paints, stains etc. $\square$ yes $\quad \square$ No

- Use of pet or plant pesticides $\square$ yes $\quad \square$ No

- Use of insect repellant $\square$ yes $\quad \square$ No

- Persistent odour $\square$ yes $\quad \square$ No

- Does your family daily use any aerosol sprays in the home $\square$ yes $\quad \square$ No

- Which one you use frequently from the following cleaning products?

$\square$ Oven cleaners $\quad \square$ Furniture polishes $\quad \square$ Household cleaners

$\square$ Carpet shampoos $\quad \square$ Home cleaners $\quad \square$ Tiles cleaner

$\square$ Air freshener $\quad \square$ Spot remover

Scouring powder that contain bleach

- Which one you use frequently from the following product as hobby $\square$ Paint stripper $\square$ Paint thinner $\square$ Wood stains $\square$ Artist's paint $\square$ Mineral spirits Turpentine oil $\square$ Lubricating greases and oils $\square$ Kerosene

- Do you have an attached garage? $\square$ yes $\square$ No

- Do you use a gas stove or oven? $\square$ yes $\square$ No

- Would you describe your home as unusually dusty? $\square$ yes $\quad \square$ No

- Do you ever use an air conditioner in the room? $\square$ yes $\quad \square$ No

- Mention that your home has following water problems. $\square$ Leaky roof $\square$ Wet basement $\square$ Leaky pipes.

- Do any furry pets live indoor? $\square$ yes $\quad \square$ No

- Proper ventilation $\square$ yes $\square$ No

- Lamp based fuel $\square$ yes $\square$ No

On the basis of above mentioned different questionnaire the survey was done by the usage of household products and activities that generates indoor air pollutants and the health symptoms in individual house was recorded in above mentioned areas.

\section{RESULTS}

The result obtained for IAPs generation is based on the survey performed in the three areas considering the lifestyle of the residents of urban, semi urban and rural area. 

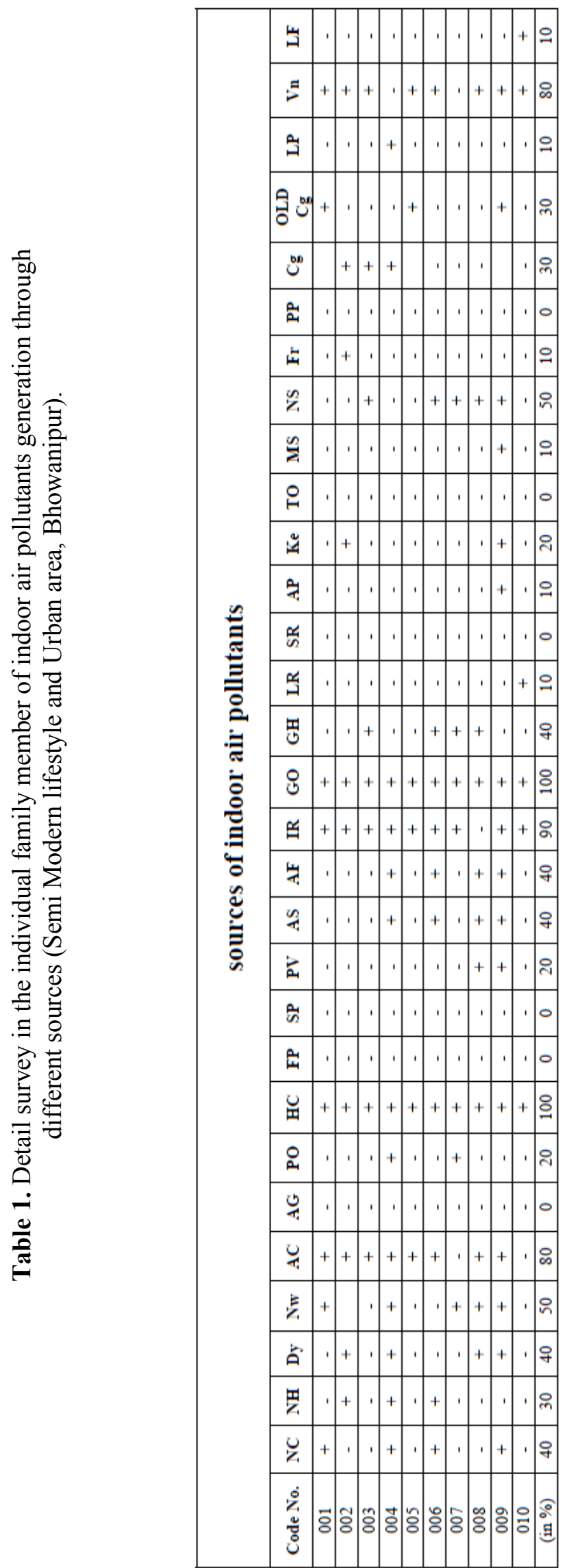

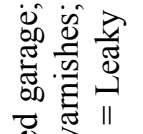

उत्)

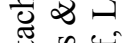

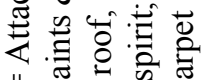

$\|$ 更

¿

正牙目

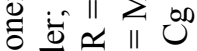

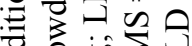

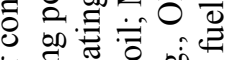

$\Rightarrow$.

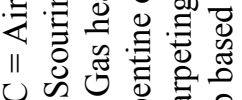

U \|\| औ

岤声

. की

놀

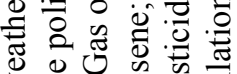

उ.

层司讨造品

$\|$ II

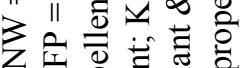

$x$ in 0

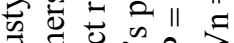

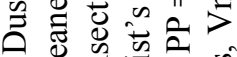

॥

ลิ

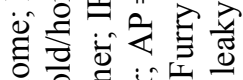

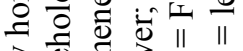

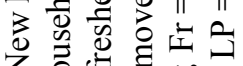

$\mathrm{Z}$ 进

“I

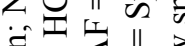

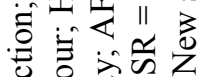

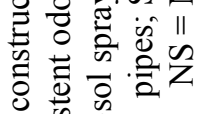

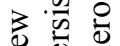

它造

II $\|$ \|

$z \& \&$ 
Table 1 indicates the general indoor air pollutants (IAPs) present in the houses of Bhawanipore area selected as urban area. The percentages indicate that the maximum sources of indoor air pollutants of about $100 \%$ come from home cleaners (HC) and gas oven (GO) followed by insect repellent (IR) of about $90 \%$ and to some extent less than before as air conditioners $(80 \%)$. The indoor air pollutants are nullified as there is proper ventilation $(80$ $\%$ ) in most of the houses. It was observed that IAPs circulated by new weatherization (NW) of about $50 \%$ followed by new construction (NC), dusts (Dy), aerosol spray (AS) and air freshener (AF) of about $40 \%$ and the pollutants are unable to persist for long as persistent odour (PO) was observed in $20 \%$ of the houses only. IAPs from, paints and varnishes (PV), turpentine oil (TO), kerosene (ke), mineral spirit (MS), lamp based fuel (LF), leaky pipes (LP) and leaky roofs (LF) ranged from 20-10\%. Main biological contaminant sources were old carpet and furry pets which scored $30 \%$ and $10 \%$ respectively.

The survey findings on semi urban Sonarpur area indicate in Table 2. The percentages indicate that the maximum sources of IAPs of about $100 \%$ come from IR, GO and GH followed by $\mathrm{HC}$ of about $90 \%$ and $\mathrm{PO}, \mathrm{AF}$ and $\mathrm{Cg}$ of about $80 \%$ and about $70 \%$ from $\mathrm{AC}$ and Dy. It was observed that the moderate amount of about $60 \%$ and $50 \%$ IAPs were circulated in houses through SP and SR and AS and Ke respectively. The IAPs generated from MS, PP and Vn were of about $20 \%$ and very less of about $10 \%$ in case of NH, FP, PV, TO, NS and LP. The physical, chemical and biological IAPs have already been established and are shown in Table 4.

The control area is a rural area mainly village and is far from the city Jhargram were surveyed. There was no new construction, weatherization, paints and varnishes and use of electronic gadgets. Sometimes they use natural insect repellent like "dhunu". they use chullah for cooking purpose and there is ample cross ventilation. They do have furry pets but most of all reside outside their houses. The usage of plants and pets pesticide is prevalent but since there is lot of ventilation and pets largely remain outside the effect of pesticides on human becomes negligible (Table 3). The percentages indicate that the maximum sources of IAPs of about $100 \%$ come from IR, GH, PP, Vn, LF but as per survey these indoor air pollutants did not persist inside the room.

The physical, chemical and biological IAPs have already been established and are listed in Table 4 (Source: Draft report for Board, California, 2005). These pollutants are asbestos, fine particulate matters and ash as physical pollutants. The chemical pollutants are carbon mono and di oxide gases, phthalates; DDT, chlordane, heptachlor, o-phenylphenol; PBDEs, Formaldehyde, Other Aldehydes, lead, benzene, chloroform, para-dichlorobenzene, methylene chloride, perchloroethylene, styrene, Benzene, formaldehyde, terpenes, styrene, phthalate esters, toluene, Propellant, pesticides, PAH, NOx, acrylamide, VOCs, acetone, HCL gas and biological pollutants are bacteria, fungi, viruses, house dust mites, animal dander; cockroaches, microbial spore.

In Table 5 the results indicate the presence of physical, chemical and biological IAPs and their sources in the indoor environment that cause several health impacts established international organization through Draft report for Board, California, 2005. In respect to established health impact data, the health symptoms were recorded after survey in two areas viz. urban and semi urban area compared with control (rural) area. The health symptoms were recorded in two areas (urban and semi urban) as eye, nose, and throat irritation, allergic reactions, respiratory irritation, aggravated asthma, influenza and other infectious diseases while no symptoms were recorded in control area. 


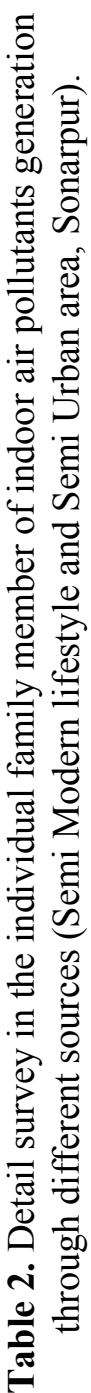

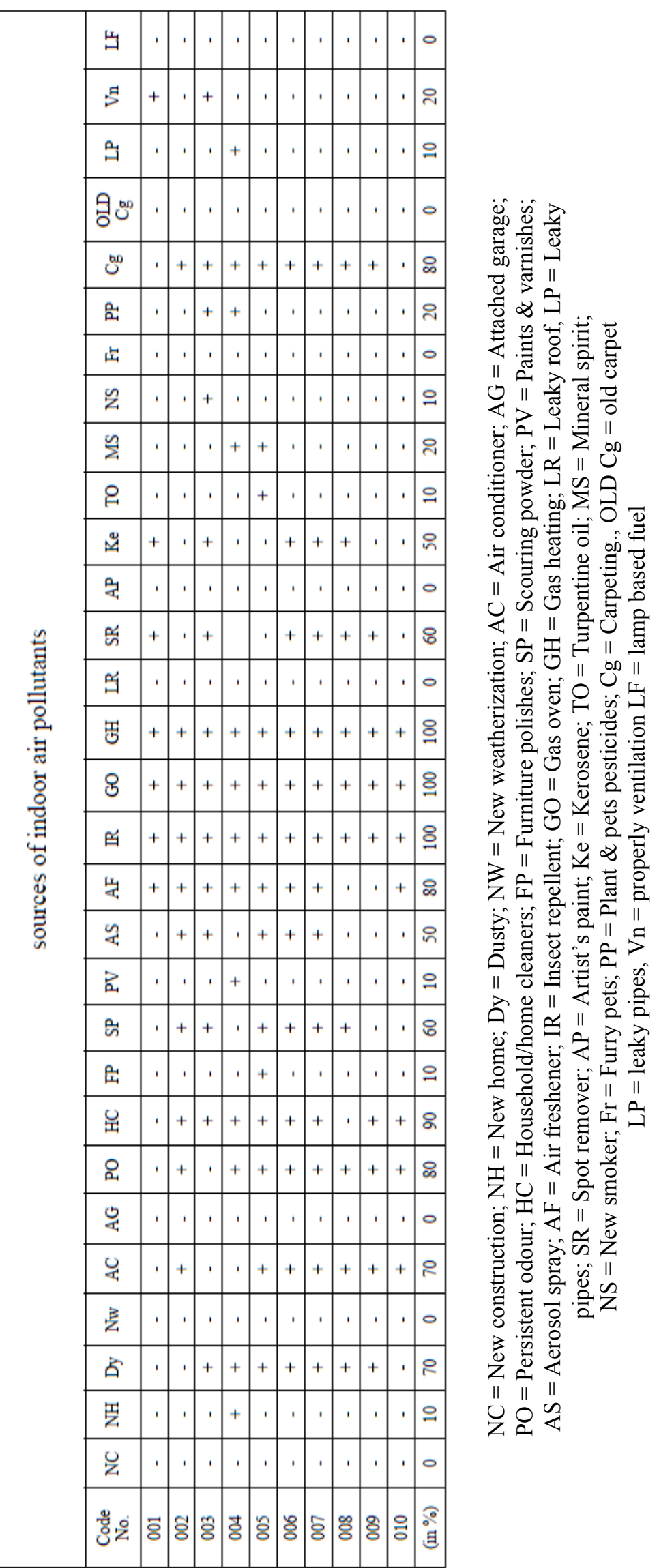



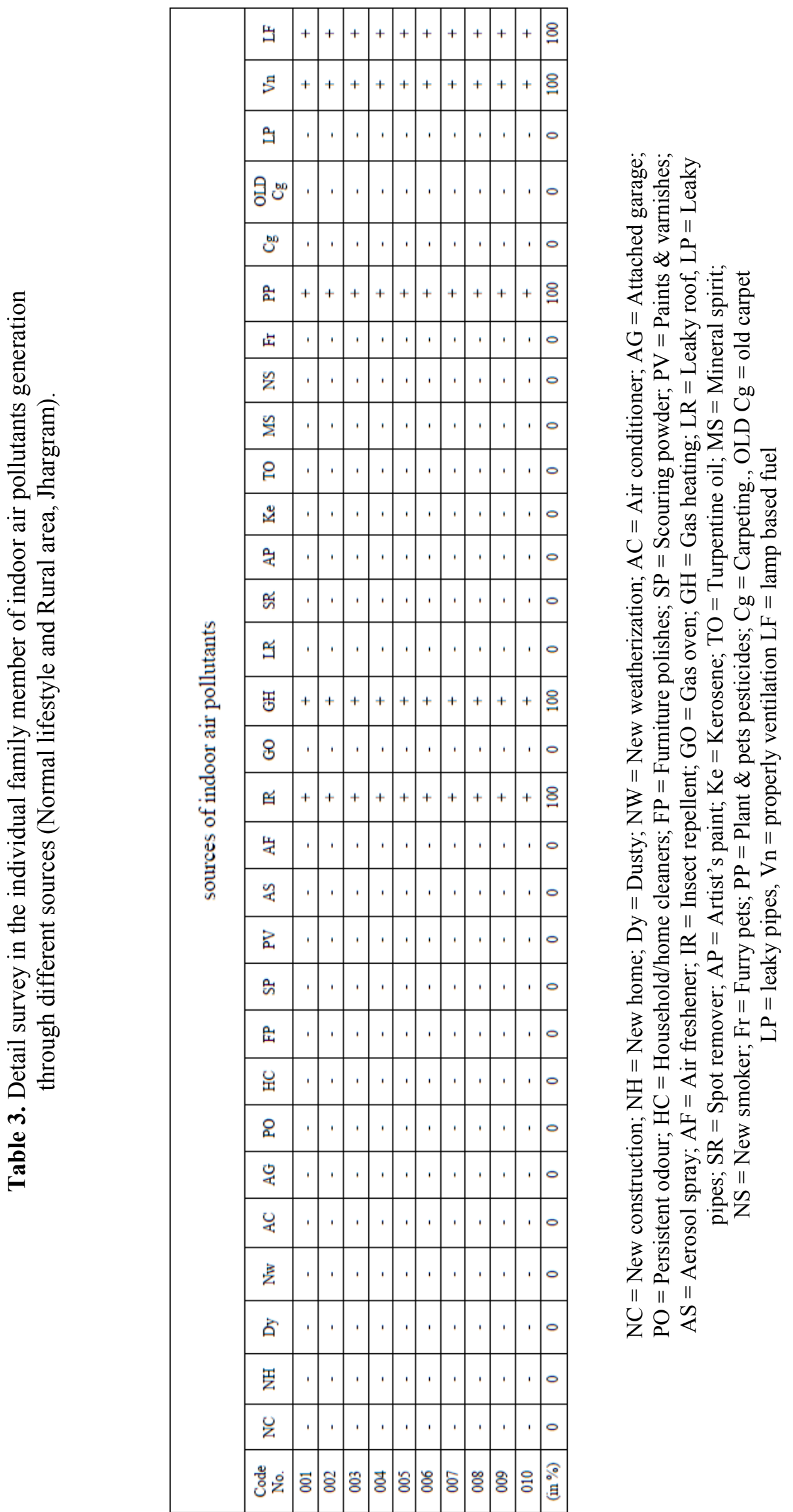
Table 4. Generation of established indoor air pollutants from different sources.

\begin{tabular}{|c|c|c|c|c|}
\hline $\begin{array}{l}\text { Sl. } \\
\text { No. }\end{array}$ & $\begin{array}{c}\text { Household } \\
\text { products/activities }\end{array}$ & $\begin{array}{l}\text { Physical } \\
\text { indoor air } \\
\text { pollutants }\end{array}$ & $\begin{array}{c}\text { Chemical indoor air } \\
\text { pollutants }\end{array}$ & $\begin{array}{l}\text { Biological indoor air } \\
\text { pollutants }\end{array}$ \\
\hline 1. & New construction & Asbestos & ---- & ---- \\
\hline 2. & New home & Asbestos & & ---- \\
\hline 3. & Dusty & $\begin{array}{l}\text { Fine } \\
\text { particulates } \\
\text { matters }\end{array}$ & ---- & $\begin{array}{l}\text { Bacteria, fungi, viruses, } \\
\text { house dust mites, animal } \\
\text { dander; cockroaches, } \\
\text { microbial VOCs) }\end{array}$ \\
\hline 4. & $\begin{array}{c}\text { New } \\
\text { weatherization }\end{array}$ & ---- & ---- & $\begin{array}{l}\text { Bacteria, fungi, viruses, } \\
\text { house dust mites, animal } \\
\text { dander; cockroaches, } \\
\text { microbial VOCs) }\end{array}$ \\
\hline 5. & Air conditioner & ---- & ---- & $\begin{array}{l}\text { Bacteria, fungi, viruses, } \\
\text { house dust mites, animal } \\
\text { dander, cockroaches }\end{array}$ \\
\hline 6. & Attached garage & $\begin{array}{c}\text { Fine } \\
\text { particulates } \\
\text { matters }\end{array}$ & Carbon monoxide & - \\
\hline 7. & Persistent odour & ---- & VOC, TVOC, $\mathrm{CO}_{2}$ & ---- \\
\hline 8. & Home cleaners & ---- & $\begin{array}{l}\text { Benzene, chloroform, } \\
\text { paradichlorobenzene, } \\
\text { methylene chloride, } \\
\text { perchloroethylene, } \\
\text { phthalates, styrene }\end{array}$ & ---- \\
\hline 9. & Furniture polishes & ---- & $\begin{array}{l}\text { Formaldehyde, Other } \\
\text { Aldehydes }\end{array}$ & ---- \\
\hline 10. & Scouring powder & ---- & $\begin{array}{l}\text { Benzene, chloroform, } \\
\text { paradichlorobenzene, } \\
\text { methylene chloride, } \\
\text { perchloroethylene, } \\
\text { phthalates, styrene }\end{array}$ & ---- \\
\hline 11. & $\begin{array}{l}\text { Paints and } \\
\text { varnishes }\end{array}$ & ---- & $\begin{array}{l}\text { Formaldehyde, Other } \\
\text { Aldehydes }\end{array}$ & ---- \\
\hline 12. & Aerosol sprays & & $\begin{array}{c}\text { Benzene, } \\
\text { formaldehyde, } \\
\text { terpenes, styrene, } \\
\text { phthalate esters, and } \\
\text { toluene. }\end{array}$ & ---- \\
\hline 13. & Air fresheners & ---- & Propellant, & --- \\
\hline
\end{tabular}




\begin{tabular}{|c|c|c|c|c|}
\hline 14. & Insect repellent & Ash & Pesticidides & ---- \\
\hline 15. & Gas oven & ---- & $\begin{array}{c}\text { Carbon monoxide, } \\
\text { PAH, NOx, } \\
\text { Acrylamide }\end{array}$ & ---- \\
\hline 16. & Gas heating & ---- & $\begin{array}{c}\text { Carbon monoxide, } \\
\text { PAH, NOx, } \\
\text { Acrylamide }\end{array}$ & ---- \\
\hline 17. & Leaky roof & ---- & ---- & $\begin{array}{l}\text { Moulds, fungus microbial } \\
\text { spores }\end{array}$ \\
\hline 18. & Leaky pipe & ---- & ---- & $\begin{array}{l}\text { Moulds, fungus, microbial } \\
\text { spores }\end{array}$ \\
\hline 19. & Spot remover & ---- & VOCs, acetone, $\mathrm{HCl}$, & $\begin{array}{l}\text { Bacteria, fungi, viruses, } \\
\text { house dust mites, animal } \\
\text { dander; cockroaches, } \\
\text { microbial spores }\end{array}$ \\
\hline 20. & Artist s paint & ---- & $\begin{array}{l}\mathrm{Pb}, \text { Formaldehyde, } \\
\text { Other Aldehydes }\end{array}$ & ---- \\
\hline 21. & Kerosene & ---- & $\begin{array}{l}\text { PAH, Carbon } \\
\text { Monoxide }\end{array}$ & ---- \\
\hline 22. & Terpentine oil & ---- & $\begin{array}{l}\text { PAH, Carbon } \\
\text { monoxide }\end{array}$ & ---- \\
\hline 23. & Mineral spirit & ---- & $\begin{array}{l}\text { Carbon monoxide, } \\
\text { vocs }\end{array}$ & ---- \\
\hline 24. & New smoker & Ash & $\mathrm{CO}, \mathrm{PAH}$ & ---- \\
\hline 25 . & Furry pets & ---- & ---- & $\begin{array}{l}\text { Bacteria, fungi, viruses, } \\
\text { house dust mites, animal } \\
\text { dander }\end{array}$ \\
\hline 26. & $\begin{array}{l}\text { Plant and pest } \\
\text { pesticide }\end{array}$ & ---- & $\begin{array}{l}\text { Phthalates, DDT, } \\
\text { chlordane, heptachlor, } \\
\text { ophenylphenol, } \\
\text { PBDEs }\end{array}$ & ---- \\
\hline 27. & Carpeting & ---- & Formaldehyde, VOCs & ---- \\
\hline 28. & Old carpeting & ---- & ---- & $\begin{array}{l}\text { Bacteria, fungi, viruses, } \\
\text { house dust mites, animal } \\
\text { dander; cockroaches, } \\
\text { microbial spore }\end{array}$ \\
\hline 29 & Proper ventilation & IAPs diffused & IAPs diffused & IAPs diffused \\
\hline
\end{tabular}


Table 5. Established health impacts and observed symptoms by indoor air pollutants from different sources.

\begin{tabular}{|c|c|c|c|c|c|}
\hline \multirow{2}{*}{$\begin{array}{l}\text { Sl. } \\
\text { No }\end{array}$} & \multirow{2}{*}{$\begin{array}{l}\text { Major } \\
\text { IAPs } \\
\text { source }\end{array}$} & \multirow{2}{*}{$\begin{array}{l}\text { Household } \\
\text { products / } \\
\text { activities }\end{array}$} & \multirow{2}{*}{$\begin{array}{l}\text { Established health } \\
\text { impacts }\end{array}$} & \multicolumn{2}{|c|}{$\begin{array}{c}\text { Health symptoms observed after } \\
\text { survey }\end{array}$} \\
\hline & & & & Urban area & Semi-urban area \\
\hline 1. & Physical & $\begin{array}{l}\text { New construction, } \\
\text { new home, dusty, } \\
\text { attached garage, } \\
\text { furniture polishes, } \\
\text { scouring powder, } \\
\text { paints and } \\
\text { varnishes, new } \\
\text { smoker, old } \\
\text { carpeting }\end{array}$ & $\begin{array}{l}\text { Lung cancer, asbestosis, } \\
\text { mesothelioma, headache, } \\
\text { nausea, angina, impaired } \\
\text { vision and mental } \\
\text { functioning, fatal at high } \\
\text { concentrations, eye, } \\
\text { nose, and throat } \\
\text { irritation, allergic } \\
\text { reactions, aggravated } \\
\text { asthma, decreased lung } \\
\text { function, headaches, at } \\
\text { high levels: loss of } \\
\text { coordination, damage to } \\
\text { liver, kidney, brain. } \\
\text { Respiratory irritation, } \\
\text { bronchitis and } \\
\text { pneumonia in children, } \\
\text { asthma in preschool } \\
\text { children, heart disease, } \\
\text { gene mutation }\end{array}$ & $\begin{array}{l}\text { Aggravated } \\
\text { asthma } \\
\text { Respiratory } \\
\text { irritation, } \\
\text { bronchitis and } \\
\text { pneumonia in } \\
\text { children, asthma } \\
\text { in preschool } \\
\text { children, } \\
\text { Allergic } \\
\text { reactions, eye, } \\
\text { nose, and throat } \\
\text { irritation, } \\
\text { humidifier fever, } \\
\text { influenza, and } \\
\text { other infectious } \\
\text { diseases }\end{array}$ & $\begin{array}{l}\text { Eye, nose, and } \\
\text { throat irritation, } \\
\text { allergic reactions } \\
\text { Respiratory } \\
\text { irritation, } \\
\text { aggravated asthma } \\
\text { influenza, and } \\
\text { other infectious } \\
\text { diseases }\end{array}$ \\
\hline 2. & Chemical & $\begin{array}{l}\text { Attached garage, } \\
\text { persistent odour, } \\
\text { home cleaners, } \\
\text { furniture polishes, } \\
\text { scouring powder, } \\
\text { paints and } \\
\text { varnishes, aerosol } \\
\text { sprays, air } \\
\text { fresheners, insect } \\
\text { repellent, gas } \\
\text { oven gas heating, } \\
\text { spot remover, } \\
\text { artists paint, } \\
\text { kerosene, } \\
\text { turpentine oil, } \\
\text { mineral spirit, } \\
\text { new smoker, plant } \\
\text { and pesticide, } \\
\text { carpeting }\end{array}$ & $\begin{array}{l}\text { Lung cancer, asbestosis, } \\
\text { mesothelioma, headache, } \\
\text { nausea, angina, impaired } \\
\text { vision and mental } \\
\text { functioning, fatal at high } \\
\text { concentrations, eye, } \\
\text { nose, and throat } \\
\text { irritation, allergic } \\
\text { reactions, aggravated } \\
\text { asthma, decreased lung } \\
\text { function headaches, at } \\
\text { high levels: loss of } \\
\text { coordination, damage to } \\
\text { liver, kidney, brain. } \\
\text { Respiratory irritation, } \\
\text { bronchitis and } \\
\text { pneumonia in children, } \\
\text { asthma in preschool } \\
\text { children, heart disease, } \\
\text { gene mutation }\end{array}$ & $\begin{array}{l}\text { Respiratory } \\
\text { irritation eye, } \\
\text { nose, throat } \\
\text { irritation, } \\
\text { headaches, } \\
\text { allergic reactions } \\
\text { aggravated } \\
\text { asthma increased } \\
\text { susceptibility to } \\
\text { sinus and } \\
\text { respiratory } \\
\text { infections, } \\
\text { bronchitis nausea } \\
\text { pneumonia in } \\
\text { children, asthma } \\
\text { in preschool } \\
\text { children, }\end{array}$ & $\begin{array}{l}\text { Respiratory } \\
\text { irritation eye, } \\
\text { nose, throat } \\
\text { irritation, } \\
\text { headaches, } \\
\text { allergic reactions } \\
\text { aggravated asthma } \\
\text { respirator y } \\
\text { infections, } \\
\text { bronchitis nausea }\end{array}$ \\
\hline 3. & Biological & $\begin{array}{c}\text { Dusty, new } \\
\text { weatherization, air } \\
\text { conditioner, } \\
\text { leaky roof, leaky } \\
\text { pipe, furry pets, } \\
\text { old carpeting } \\
\end{array}$ & $\begin{array}{l}\text { Allergic reactions, } \\
\text { asthma, eye, nose and } \\
\text { throat irritation, } \\
\text { humidifier fever, } \\
\text { influenza, and other } \\
\text { infectious diseases }\end{array}$ & $\begin{array}{c}\text { Allergic } \\
\text { reactions,asthma, } \\
\text { eye ,nose, throat } \\
\text { irritation, } \\
\text { infectious } \\
\text { diseases } \\
\end{array}$ & $\begin{array}{l}\text { Allergic reactions, } \\
\text { asthma, eye ,nose, } \\
\text { throat irritation, } \\
\text { infectious diseases }\end{array}$ \\
\hline
\end{tabular}




\section{DISCUSSION AND CONCLUSION}

The present IAP survey was done in the residential buildings on the basis of urban and semi urban area where the residents used several household products containing synthetic chemicals and activities in which different physical, chemical and biological pollutants are generated, when compared with control (rural) area, indicate that these indoor air pollutants may cause chronic health impacts to the human.

The generation of indoor air pollution by household products and activities in the residential as well as office buildings have already been studied internationally by many researchers. Major research works have been conducted on the products and health impacts (Molhave, 1986; Molhave, 1991; Rivers, Pleil and Wiener, 1992; Bluyssen et al., 1996; Seifert, 1999; Pitten, Bremer and Kramer, 2000; Chan, 2003) by physical, chemical and biological indoor air pollutants (IAPs) but few works have been done in context to India (Kirk, 2000), but many researchers have been documented on rural and/or urban slum area, no one has tried to establish generation of IAPs by household products and activities in residential buildings in relation to health hazards symptoms on modern lifestyle in urban and semi urban area compared to normal lifestyle in rural (control) area.

It was observed in the present results that people of modern lifestyle in an urban and semi urban area shows the major usage of household products and activities that generated IAPs in the indoor environment with some health hazards symptoms. On contrary, people of normal lifestyle in rural area possesd no symptoms because the houses have proper ventilation and very rarely they use household products and activities that generate IAPs in relation to urban and semi urban area (Table, 1, 2, 3 and 5). It was previously known that raw fuels like coal, wood, dung etc. are generated indoor air pollution in rural area (Kirk, 2000; ICMR Bulletin, 2001) but the IAPs may decrease with proper ventilation and lesser the health impacts, which are observed in the present survey.

The present survey refers with other research works in relation to the physical, chemical, and biological characteristics of air in the indoor environment within a home, building, or an institution or commercial facility. IAP is a concern in the developed countries, where energy efficiency improvements sometimes make houses relatively airtight, reducing ventilation and raising pollutant levels. Different conditions are responsible for indoor air pollution in the rural areas and the urban areas. In the urban area, the concentration of volatile organic compounds (VOCs) measured in indoor air are often significantly higher than outdoors. The data have already been established on various potential origins such as human activities, infiltration from outdoor air, heating ventilation and air conditioning (HVAC) systems (Wolkoff, 1995; Fanger, Lauridsen, Bluyssen, et al. 1988), bacterial and fungal activities (Rivers, Pleil and Wiener, 1992; Batterman, Bartoletta and Burge, 1991) and product emissions (Wallace, Pellizzari, Leaderer, et al. 1987; Wolkoff 1995; Wolkoff, Jensen, Kjaer, et al. 1996; Hodgson, Rudd, Beal, et al. 2000; WHO, 2000).

The concentrations are usually orders of magnitude below the occupational threshold limit values (TLVs). However, some VOCs may be present above their human odour thresholds (OTs). Beside odour annoyance, VOCs at sub-TLV level may cause non-specific health effects such as eye and upper respiratory airway irritation, headache and increased weariness (Molhave, 1986; Molhave, 1991; Seifert, 1999 and Pitten, Bremer and Kramer, 2000; Chan, 2003). The health hazards symptoms found in the present survey after relevant questionnaire may have generated from the usage of household products and activities in the closed chamber and unknowingly lesser ventilation facilities. In case of rural area, the present survey emphasized that people after using few of the household products like IR, LF and GH 
(fuel like wood, coal, dung and crop parts) mainly and activities in the homes due to proper ventilation and awareness, which may not be shown health symptoms by IAPs but previously it was reported that severe health impacts found in women, children and old age people by IAPs especially fuel burning in their home (Kirk, 2000; ICMR Bulletin, 2001).

In the present study it was concluded that the generation of IAPs is mainly from household products and activities in the urban and semi urban area due to less ventilation facilities when compared to rural (control) area. As we know from the previous research work in Indian cities, the concentrations of IAPs often exceed the toxic limits (Kirk, 2000; ICMR Bulletin, 2001). This survey is a preliminary assessment of IAPs generation by using various household products and activities in a closed room of residential buildings but further researches are needed in relation to measurement of physical, chemical and biological pollutants in closed room of residential buildings and also health hazards study of residents by haematological, biochemical, enzymological and genotoxicological parameters. The observed health symptoms after survey through questionnaire may be the generation of IAPs and lesser ventilation facilities in the survey buildings when compared to control (rural) area.

\section{ACKNOWLEDGEMENT}

The authors convey their gratitude to the Department of Environmental Science, University of Calcutta, for providing the necessary infrastructure for doing this survey work.

\section{References}

[1] Batterman, S., Bartoletta, N., Burge, H., Proceedings of the 84th Annual Meeting and Exhibition of the air and waste management association (1991) 91-62.9 Vancouver.

[2] Bluyssen, P. M. Commission of the European Communities, Directorate-General XI1 for Science, Research and Development (1991).

[3] Bluyssen, P. M., de Oliveira Fernandes, E., Fanger, P. O., Groes, L., Clausen, G., Roulet, C. A, Bernhard, C. A. Valbjerrn, O., European Audit Project to Optimize Indoor Air Quality and Energy Consumption in Ofice Buildig, 1995a.

[4] Bluyssen, P. M., de Oliveira Fernandes, E., Groes, L., Clausen, G., Fanger, P. O. Albjorn, V., Bernhard, C. A., Roulet, A., Indoor Air 6 (1996) 221-238.

[5] Bluyssen P, Cochet C, Fischer M, et al., European Comission Report No.18 (1997).

[6] Chan, W, R et al., LBNL Report \#53367 (2003).

[7] Clausen, G., Pejtersen, J., Bluyssen, P. M., Copenhaven, Technical University of Denmark and Delft, TNO-Building and Construction Research, 1993.

[8] Fanger P. O., Lauridsen, J., Bluyssen, P. et al. Energy Build 12 (1988) 7-19.

[9] Health Canada. Exposure guidelines for residential. Indoor Air quality; A report of the Federal-Provincial Advisory Committee on Environmental and Occupational health, Ottawa: health Canada. Publication_Communications, Ottawa, K1A0K9 (1995).

[10] Hodgson, A. T., Rudd, A. F., Beal, D. et al., Indoor Air 10 (2000) 178-192.

[11] ICMR Bulletin. Indoor air pollution in india - A major environmental and public health concern 31(5) (2001). 
[12] Kirk, R. S., PNAS 9724 (2000) 13286-13293.

[13] Molhave, L., Indoor Air 1 (1991) 357-376.

[14] Molhave L, Bach B, Pedersen O. F., Environ International 12 (1986) 167-165.

[15] Pitten, F. A., Bremer, J., Kramer, A., Dtsch med Wschr 125 (2000) 545-550.

[16] Rivers, J. C., Pleil, J. D., Wiener, R. W., J Exp Anal Env Epidem 1 (1992) 177-188.

[17] Seifert, B., Bundesgesundheitsbl-Gesundheitsforsch-Gesundheitsschutz 42 (1999) 270-278.

[18] Wallace, L. A., Pellizzari, E, Leaderer, B. et al., Atmospheric Environment 21(2) (1987) 385-393.

[19] Wolkoff, P., Indoor Air 3 (1995) 1-73.

[20] Wolkoff P., Proceedings of the 7th International Conference on Indoor Air Quality and Climate. Indoor Air 96(1) (1996) 579-584 Nagaya.

[21] Wolkoff, P., Clausen, P. A., Nielsen, P. A., Indoor Air 5 (1995) 196-203.

[22] Wolkoff, P., Jensen, P., Kjaer, U., et al., Indoor Air 96(4) (1996) 331-336.

[23] World Health Organization (WHO), Air quality guidelines for Europe, 2nd Edition, WHO regional Pubs, European series, No. 91 (2000).

[24] World Health Organization (WHO), Based on the WHO-USAID Global Consultation on the Health Impact of Indoor Air Pollution and Household Energy in Developing Countries (Meeting report), Washington, DC, 2002. 